\title{
Depression among Women in Menopause
}

\author{
Noureen* \\ Master degrees in Public Health and Political Science, Quiad-e-Azam University, Pakistan
}

Submission: April 10, 2017; Published: April 20, 2017

*Corresponding author: Noureen, Master degrees in Public Health and Political Science, Quaid-e-Azam University, Islamabad, Pakistan Email: alshifanoor@yahoo.in

Abbreviations: IT: Interpersonal Therapy; CBT: Cognitive Behavior Therapy; MBCT: Mindfulness Based Cognitive Therapy

\section{Introduction}

Depression is more common in women while at the time of menopause the transition may be a certain risk. Declining estrogen levels are associated with hot flashy menopause. Some women feel constant state of PMS (premenstrual syndrome). General symptoms of depression and anxiety with mood disturbance are common during menopause transition. The symptoms are more severe with sleep disturbance, vasomotor and the following surgical menopause. Developing of stressed and depressed mood is up to three times more likely that of women in premenopausal period. There is a greater likelihood for those women who have history of depressive illness. There are different presentations of depression in menopause as it appears unique with low level depressive symptoms, fatigue, anger and increased sleep disturbance. These symptoms are non-specific somatic and makes the diagnosis more difficult particular overshadow the cognitive specific ones. Women are present with depressive symptoms and mood changes but generally not meet the DSM5 criteria of diagnosis [1].

There are many risk factors for depression. For instance, continuing difficulties, loneliness with long term isolation, long term unemployment, prolonged exposure to work stress and living in abusive uncaring relationship are more likely risk factors than recent life stresses. Indeed, a recent event like losing job or relationship can be a trigger for those who are already at risk as of past hardships. However, personal factors are common as depression can run in families and some women at increased genetic risk. It is like genes loaded the gun while lifestyle pulls the trigger. So life circumstances with genetic factor are likely to have important influence. Some women are at more risk due to their personality of having tendency to worry too much, lower self-esteem, sensitive, perfectionist, negative and self-critical to personal criticism.

Substance use like drugs and alcohol are leading causes of depression. This is interlinked with depression and substance use. Then there are some serious medical illnesses that can trigger depression in many ways. Serious illnesses bring depression directly and contribute stressful worries with long term management of chronic pains. Some risk factors in perimenopausal are including hot flushes, disturbed sleep, stressful life events, negative attitude towards menopause and co-morbid health conditions.

\section{Symptoms of Depression}

Depressed mood, loss of interest in daily activities and pleasure for more than two weeks. Impaired social, educational and occupational functions nearly every day either subjective report observation by others. Significant change in appetite, insomnia or hypersomnia, Psychomotor agitation, fatigue, loss of worth, guilt, low ability to concentrate and suicidal thoughts are major symptoms [1].

Many scientists suggest that midlife depression risk may be related to personal or a family history of depression. During the perimenopause estrogen levels decline gradually that bring depression which some studies suggest while the role changes and life stressors come with middle age. The onset of menopause and depression share many same symptoms including irritability, sleep problems, fatigue and anxiety. Due to same symptoms depression may go undiagnosed and untreated in those women who think it a natural part of aging. This untreated depression can increase the risk of developing many other serious medical conditions like increase risk of fractures due to loss of bone mineral density and heart attack.

\section{Treatment For Depression}

Women should be screened in the menopause transition specially for clinically significant depression. The management should be more comprehensive that address psychosocial stressors. Psychological therapies and modalities with pharmacotherapies can improve the feelings of wellbeing and 
quality of life. Healthy food and exercise can improve good mood. Psychological therapies for instance behavior therapy, interpersonal therapy (IT), cognitive behavior therapy (CBT) and mindfulness based cognitive therapy (MBCT) should be utilized. HRT, may be appropriate relief therapy for menopausal symptom in some depressed women [2]. A mild to severe depression need antidepressant medication [3]. Staying connected with family and friends can nurture wellbeing. Self-supporting skills such as yoga, rhythmic breathing and meditation are helpful in menopause. Some people go for herbal remedies but unfortunately there is very little scientific evidence that support alternative treatment for depression. As these remedies are not regulated so without standardized information on ingredients or dosing instructions end up danger to health. While some supplements may have negative interaction with antidepressants. There are number of actions a woman can take at her own to manage the depression symptoms and feel better. Self-care plans strategies including support system by family members, brisk walk physical activity, stress management through realistic expectations, better sleep and sound nutrition are keys to manage depression.

\section{References}

1. American Psychiatric Association (2000) Diagnostic and Statistical Manual of Mental Disorders Fourth Edition.

2. Clayton AH, Ninan PT (2010) Depression or menopause? Presentation and management of major depressive disorder in premenopausal and postmenopausal women. Prim Care Companion J Clin Psychiatry 12(1): PCC.08r00747.

3. Hickey M, Bryant C, Judd F (2012) Evaluation and management of depressive and anxiety symptoms in midlife. Climacteric15(1): 3-9.

Your next submission with Juniper Publishers will reach you the below assets

- Quality Editorial service

- Swift Peer Review

- Reprints availability

- E-prints Service

- Manuscript Podcast for convenient understanding

- Global attainment for your research

- Manuscript accessibility in different formats (Pdf, E-pub, Full Text, Audio)

- Unceasing customer service

Track the below URL for one-step submission https://juniperpublishers.com/online-submission.php 